\section{NEW ZEALAND DEPARTMENT OF SCIENTIFIC AND INDUSTRIAL RESEARCH}

\author{
ANNUAL REPORT FOR $1952-53$
}

\begin{abstract}
THE twenty-seventh annual report* of the Department of Scientific and Industrial Research, New Zealand, covers the year ended March 31, 1953. It includes the Minister's statement, the Secretary's report and reports from the several branches of the Department, as well as from the Cawthron Institute, the Commonwealth Agricultural Bureaux, the research associations, the Manufacturers' Research Committee and the university colleges to which grants were made by the Department. The Minister's statement, stressing the way in which, particularly in the primary industries, the Department is assisting to put the results of scientific effort into practical use more rapidly than ever, and the satisfactory extent to which the Department has succeeded in establishing effective collaboration with other bodies in dealing with economic scientific problems, suggests that it is now an appropriate time to review the basis upon which research associations are financed by industry and by the State.
\end{abstract}

The Secretary's report notes a reduction in staff during the year from 1,012 to 931 , that in professional staff being from 402 to 374 . There were also considerable reductions in capital charges, in purchases of equipment and supplies and in travelling expenses, but reductions were spread as widely as possible. A critical analysis of the Department's expenditure of $£ 1,020,720$ estimates that 26 per cent was on longterm applied research; 22 per cent on scientific services for other government departments; 17 per cent on research and services to primary industry; 10 per cent each for defence science and on administration, information service, etc. ; 7 per cent on research and services to manufacturing industry ; 5 per cent on research grants; and 3 per cent on grants to British Commonwealth and international scientific institutions. It is estimated that the expenditure on research, as distinct from services, is probably about 43 per cent, and, reviewing the results of this expenditure over the past twenty-seven years, the Secretary points out that grassland research has enabled New Zealand, by breeding new strains of pasture plants and studying their management and utilization, to attain front rank as a pasture country with an exceptionally high yield of meat, butterfat and wool per acre. The annual production of fodder has been largely increased, the season of grass growth being extended by at least two months. New methods have been used for combating such serious diseases as facial eczema and bloat, and a considerable export trade has been built up in pedigree grass and clover seeds.

Soil surveys of the whole of New Zealand have been completed, and on this basis areas of erosion, of deficiency in lime and phosphate, and of the occurrence of plant and animal deficiency diseases have been mapped and the foundation thus laid for the utilization of the Dominion's soil resources. The areas liable to bush sickness have been defined and are now being brought into successful production. Research into plant diseases has brought many of them under complete control and others have been

* New Zealand. Twenty-seventh Annual Report of the Department of Scientiflc and Industrial Research. Pp. 108. (Wellington: Government Printer, 1953.) made amenable to spray treatment. The fruitgrowing industry has been provided with sound methods for the control of fungal and bacterial diseases and of insect pests, and bunt and smut diseases of barley and wheat are now rare. Research in fruit transport has eliminated the serious losses which were common twenty-five years ago in shipments to the United Kingdom. The serious physiological disease of apples, known as corky core, has been traced to boron deficiency and is easily and cheaply remedied. The wheat industry has been provided with a series of varieties unsurpassed in yield and quality of flour and in marked contrast to the Tuscan variety which they have replaced. The two most serious insect pests of pastures, grass grub and grass caterpillars, have been brought under control economically, as well as the diamond back moth which in bad seasons inflicted losses of turnips, rape and cabbage estimated at tens of thousands of pounds; and methods have been found by which South African citrus fruit may be imported to New Zealand without risk of introducing serious insect pests.

Recent research has discovered the cause of the yellow-leaf disease threatening the phormium industry and has indicated remedial measures which have removed the worst threat. Research in the tobacco industry since 1920 has led to the area under this crop being doubled as well as the yield of leaf per acre. The linen-flax industry has been established on research carried out by the Agronomy Division at Isincoln, the fish-liver oil industry on the investigations of the Fats Research Laboratory into the vitamin content of New Zealand fish livers, and the agar industry on the seaweed researches of the Botany Division and the Dominion Laboratory. These and other advances due to the research activities of the Department have afforded savings in any one year that would repay the whole of the State expenditure of nearly $£ 8$ millions on the Department during the past twenty-seven years.

The Secretary points out that so far no agreement has been reached regarding an adequate organization for the scientific problems of the building industry : in the Department's view, such an organization should be capable of adapting advances in building research institutions overseas to the special conditions of New Zealand, of undertaking research into New Zealand building problems and of disseminating knowledge to the industry. Progressive improvement in accommodation in many branches of the Department is recorded, including new premises for a section of the Geological Survey and for the Geophysics Division. The removal in the near future of the Botany Division headquarters to Christchurch should relieve the serious overcrowding in this Division of many years past.

Outstanding economic achievements of the year include savings estimated at $\mathfrak{£ 3 0 , 0 0 0}$ to Auckland tomato growers through the elimination of Botrytis disease by incorporation of a special fungicide in the hormone sprays used to induce setting of the fruit from early flower trusses. Investigations with the use of hormone sprays have now indicated that some 70 per cent of the cost of thinning apples in Hawke's Bay orchards can be avoided, with savings estimated at $£ 20,000$ annually, while in the fruit-growing districts of Central Otago treatment of pears, peaches and nectarines with zinc salts has checked die-back and restored normal vigour. Investigations on frost injury to fruit trees by facilitating more reliable pre- 
diction of dangerous frosts has offered operating economies in fuel and labour. The Crop Research Division has produced strains of Blue Prussian and Greenfeast peas of proved resistance to wilt diseases, thus permitting higher yields and the more frequent use of peas in cropping rotation.

Tests in ground infested with black root-rot disease indicate that two varieties of tobacco introduced from the United States give yields higher by more than $500 \mathrm{lb}$. of leaf per acre, thus enabling tobacco to be grown profitably on areas abandoned on account of infestation by root-rot. Inoculation of the soil with methyl bromide has been shown to be as effective as steam sterilization for control of weeds in tobacco seedling beds, and the application of maleic hydrazide when the tops are removed eliminates all subsequent labour in the removal of lateral shoots. A considerable measure of control of stone fruit blast has been obtained by the Plant Diseases Division with the antibiotic streptomycin; nodule bacterial work in the same Division has produced a strain that promotes rapid establishment of clover in the raw pumice soils of the Wairakei-Tampo area, and complete control of thrips on onions has been obtained with DDT spray applied as an emulsion. The headsnut disease and cutworm pests, which have been making serious inroads on the yields of maize in Poverty Bay, have been brought under control by means of a heavy dressing of fungicide in which an insecticide that desls with the cutworms is incorporated.

By a simple modification of the diffusion process of treating timber with boric acid, in which the green sawn timber is passed through a bath or spray of concentrated boric acid/borax solution and then held in block-stacks for a specified period, an inexpensive method of treatment has been evolved which was being tested on a semi-commercial scale. Promising results in breeding a new improved type of perennial ryegrass have been obtained in firstgeneration hybrids from perennial and short-rotation rye-grass, and the establishment of a well-balanced pasture-sward during the initially difficult stages has been facilitated by halving the amount of grass seed in an ordinary pasture mixture. At the $\mathrm{Te}$ Awa hill station the carrying capacity of pastures was increased to four ewes per acre compared with one wether a few years ago. Investigations on the control of grass grub and perina, which cause losses estimated at $£ 6$ millions annually, are continuing; but meanwhile the Entomological Research Station's recommendations for a DDT treatment costing less than $£ 1$ an acre has been substantiated.

Detailed soil surveys of the Gisborne Plains, Foxton Sands, Canterbury Plains and Downlands and the Heathcote Valley horticultural areas, and detailed geological and geophysical surveys of the Wairakei and Te Teko geothermal areas were completed during the year. Surveys were being extended northwards to the Waiotapu area, and the use of the steam resources now being tapped was under consideration for the production of heavy water. The Department was also associated with the scientific aspects of the completely successful shipment of chilled beef, the first since pre-war years, by the New Zealand Meat Producers' Board to London on the Dominion Monarch. Various sections of the Department gave valuable assistance to several aspects of the work on the Maraetai hydroelectric dam, including stress and vibration measurements, and advice on paints and their protection; a special feature was the examination by the gamma-ray equipment of the Dominion Physical Laboratory of all welds within the metal of the penstock controls and the location of flaws. In consequence, repairs to the penstock equipment were made in New Zealand, and the dam was brought into operation several months earlier than scheduled. The five industrial research associations of the Department all had successful years, and the Manufacturers' Research Committee gave special attention to the organization of trade research groups within the Auckland Industrial Development Laboratories and the Canterbury College Industrial Development Department so as to provide scientific assistance to manufacturing industries too small to form research associations.

\section{ROYAL OBSERVATORY, CAPE OF GOOD HOPE \\ REPORT FOR 1952}

$\mathrm{T}$ THE report of the Royal Observatory, Cape of Good Hope*, for 1952, which has recently become available, shows that it was "a reasonably satisfactory" year for the Observatory. The weather, from the point of view of observing, was well above average during the first part of the winter, and good progress was made with the observing programme both at the Cape and at Pretoria. It was very satisfactory that the $E$-region zero-point programme was completed in a year, thus providing the material for rounding off the first half of the standard magnitude programme on which the Observatory has been engaged for a long time.

As stated in the report for 1951, arrangements were made for an examination of the declination axis of the Victoria telescope, in consequence of which it was out of action during a great part of 1952. Temporary repairs were not satisfactory, the motion of the telescope being still very stiff, and it was decided to fit modern roller and thrust bearings. This was not completed before January 1953 ; but it was possible to use the instrument for short periods between the various stages. The motion of the telescope is now quite smooth and easy, but it wos used on only 63 nights during the whole year as compared with 177 nights in 1951. The opportunity was taken during the periods when the instrument was out of action to remove from the pier the old and massive weight-driven clock which was superseded in 1950 by a comparatively small electric synchronous motor, and at the same time to renew much of the electric wiring and to fit a new slow-motion motor. The tube of the 24-in. telescope was shortened by three inches in preparation for the fitting of the new lens cell recently made by the firm of Cox, Hargreaves and Thomson.

The astrographic refractor was used on 178 nights32 more than during the previous year-in spite of the fact that it was out of commission for about three weeks in October and November in connexion with the remounting of the photometric cameras. Since their return from Cambridge, they have been adapted to use standard $16 \mathrm{~cm} . \times 16 \mathrm{~cm}$. plate-holders and have been fitted with new exposing-shutters working in front of the lenses and with an extra long dew-cap fitted with internal diaphragms to keep out

* Report of Her Majesty's Astronomer at the Cape of Good Hope to the Secretary of the Admiralty for the year 1952. Pp. 16. (Cape of Good Hope: Royal Observatory, 1952.) 